\title{
Comparative study of two potential recuperating converters in DC railway electrification system for harmonic mitigation
}

\author{
Z. H. Choi, C. L. Toh, M. H. Z. Hilmi \\ Department of Electrical Power Engineering, Universiti Tenaga National, Malaysia
}

\begin{tabular}{l}
\hline Article Info \\
\hline Article history: \\
Received Nov 25, 2018 \\
Revised Feb 12, 2019 \\
Accepted Mar 8, 2019 \\
\hline
\end{tabular}

Keywords:

Recuperating converter Modular multilevel converter Cascaded H-bridge converter Level-shifted PWM Harmonic mitigation

\begin{abstract}
The regenerative braking energy produced by Light-Rail-Transit (LRT) train is commonly transferred back to power grid via a conventional three-phase inverter (recuperating converter). Although this is a cost saving solution but the ac grid current and voltage waveforms were distorted. Hence passive filters are integrated to mitigate the harmonics. This paper proposed to replace the conventional inverter system with a multilevel converter. Cascaded H-Bridge (CHB) converter and Modular Multilevel Converter (MMC) are selected to be evaluated in this paper due to their modularity structures. The aim of this study is to determine the most potential multilevel converter to be implemented without additional passive filters. Nine-level $\mathrm{CHB}$ and nine-level MMC converters are modeled with MATLAB/Simulink simulation tool. Both converters are modulated with Level-Shifted Pulse Width Modulation technique. The output voltage and current waveforms generated by $\mathrm{CHB}$ and MMC are presented with full analysis. It is concluded that MMC converter is more suitable to be used as a recuperating converter. It produces a clean voltage and current waveforms. The voltage and current Total Harmonic Distortion (THD) indexes are found approximate to $8 \%$ and $3 \%$.
\end{abstract}

Copyright (c) 2019 Institute of Advanced Engineering and Science. All rights reserved.

\section{Corresponding Author:}

C. L. Toh,

Department of Electrical Power Engineering,

Universiti Tenaga Nasional,

Jalan Ikram-Uniten, 43000 Kajang, Selangor, Malaysia

Email: chuenling@uniten.edu.my

\section{INTRODUCTION}

DC railway electrification system is normally used to power up the commuter trains, such as tram, Light-Rail-Transit (LRT) and Mass-Rapid-Transit (MRT) in urban cities [1]. A tram and Light-Rail-Transit (LRT) system are designed to commute low capacity of passenger in a travelling speed below $70 \mathrm{~km}$ per hour. Hence, the DC voltage supply is rated at $750 \mathrm{~V}$. On the other hand, a Mass-Rapid-Transit (MRT) system may employ a higher DC voltage rating $(1.5 \mathrm{kV}$ or $3 \mathrm{kV})$ to commute higher capacity of passenger. In general, MRT train is capable to travel in the speed above $70 \mathrm{~km}$ per hour.

All types of commuter trains will experience four operating modes to move from one passenger station to the subsequent station [2]. These operating modes include accelerating mode, motoring mode, coasting mode and braking mode. Upon departure, massive electric power will be drawn to accelerate a train from standstill to the demanded line speed. The train will then shifted to motoring mode and travels at a constant speed. When the train is prepared to arrive at the next passenger station, it will first entered coasting mode. In this mode, the electric motor is not being energized; the train is moved by its momentum with the speed dropping accordingly due to the friction force. Eventually, the braking mode will be activated to stop the train accurately at the passenger station. A train will act as a generator in braking mode where about $44 \%$ $-56 \%$ of regenerative braking energy can be recovered [3-5]. 
Majority of the DC traction power substation is designed with rectifier transformer couple with a twelve-pulse traction rectifier (uncontrolled) [6]. This design is capable to regulate a nominal DC voltage for commuter trains operation. The advantage of this configuration is to keep the total harmonic distortion of the AC line current in the acceptance range of standard [7]. However, this configuration does not fully utilize the braking energy. The traction rectifier only supports unidirectional current flow. As a result, the regenerative braking energy has to be dissipated through some resistor banks $[8,9]$. Some research works have proposed to utilize the regenerative energy to regulate the forward train voltage [10], power up the auxiliary loads in passenger station [11] or in trains [12]. In order to realize the abovementioned proposals, the existing traction substation has to be upgraded with a recuperating converter.

A cost saving solution is to transfer the power back to the grid $[13,14]$. As shown in Figure 1 (a), the existing traction rectifier and rectifier transformer are remain unchanged. An Active Regeneration Unit (ARU), which consists of a conventional three-phase inverter and LC filter, is added to the existing system. The DC terminal of the ARU is connected to the traction load. Whereas the AC terminal of the ARU is hooked up to the secondary side of the rectifier transformer at star winding. In [15], a three phase regenerative inverter is designed for a DC traction substation. The inverter is coupled to an independent transformer via an LCL filter as shown in Figure 1 (b). Both recuperating inverters apply Pulse-WidthModulation switching scheme. The switching frequency ranges from $1 \mathrm{kHz}$ to $3 \mathrm{kHz}$. AC passive filters are demanded to reduce the line currents and voltages distortion.

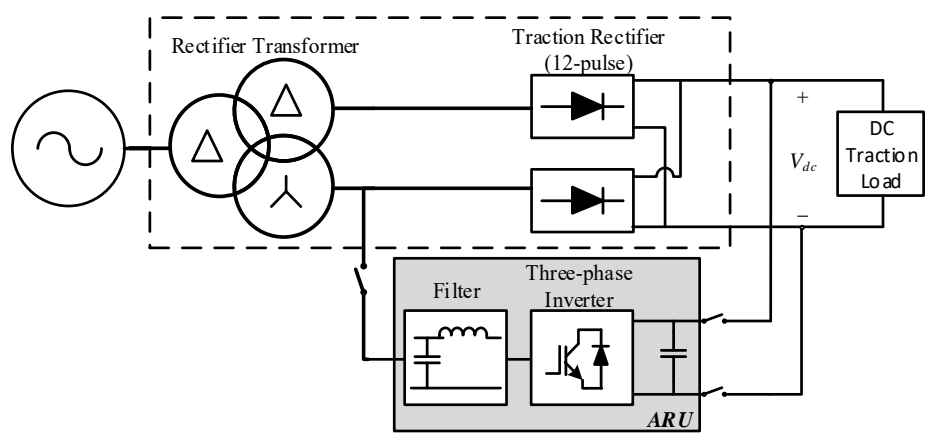

(a)

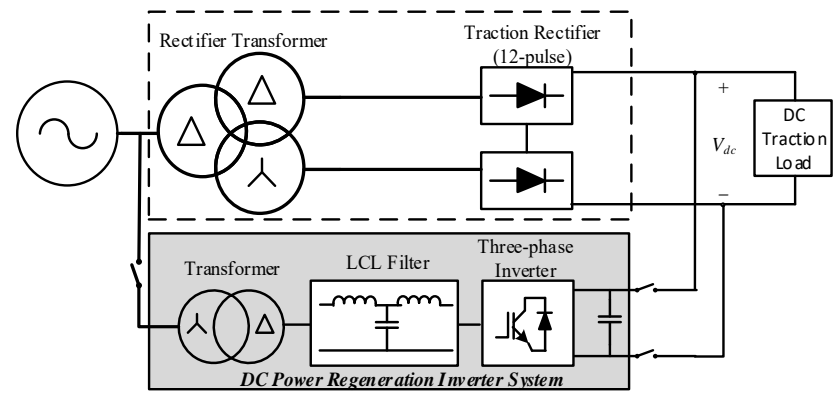

(b)

Figure 1. Recuperating converter proposals for the traction power substation (TPSS), (a) Active regeneration Unit [13], (b) DC power regeneration inverter system [15]

In order to mitigate the harmonics distortion without passive filters, advanced multilevel converter has been proposed. Figure 2 shows the proposed configuration of a multilevel converter which used to restore the regenerative energy back to the utility grid. In [16], a 17-level Cascaded H-Bridge (CHB) converter which is modulated with Level-Shifted Pulse-Width-Modulation (LS-PWM) technique manages to keep the voltage distortion as low as $8 \%$. Conversely, the configuration of the power circuit is complex by involving approximately 96 units of power semiconductors. Therefore, this paper will present a comparative study on CHB and Modular Multilevel Converter (MMC). The aim is to determine the most potential multilevel

Int J Pow Elec \& Dri Syst, Vol. 10, No. 3, Sep 2019 : 1157 - 1166 
converter to be used in TPSS which employs lesser number of power semiconductors while comply with harmonic distortion index set by IEEE Standard. Both converters will be evaluated using identical modulation technique, i.e. LS-PWM. Pure sinusoidal modulating waves will be applied in this study, recuperating intention control technique and power factor analysis will be presented in our next paper. This paper is outlined as follows. The operational principle and LS-PWM technique for CHB and MMC converters are briefly reviewed in Section 2. Section 3 presents simulation analysis and a conclusion will be presented in Section 4.

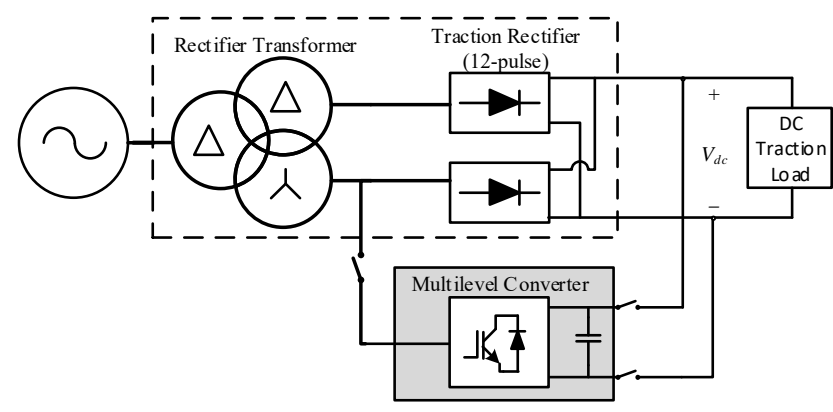

Figure 2. Proposed multilevel converter as recuperating converter

\section{MULTILEVEL CONVERTERS}

Multilevel converters are commonly used in medium voltage applications rated from $2.3 \mathrm{kV}-6.6$ $\mathrm{kV}$. Classic multilevel converters include Neutral-Point-Clamped (NPC), Flying Capacitor (FC) and Cascaded H-Bridge (CHB) converters. These converters have been commercialized with a maximum output voltage level reaching three, four and seventeen levels respectively. Advance multilevel converters topologies are continuously evolved based on these classical converters, such as H-bridge NPC (HNPC), Active NPC (ANPC), Transitor-Clamped Converter (TCC), Modular Multilevel Converter (MMC) and hybrid multilevel converters [17-19]. Since CHB and MMC offer high modularity and flexibility in configuration, they are selected in this comparative study. In general, they are classified as multi-cells converter. They employ a number of power cells which are identical in design using low rating components. Figure 3 presents the power circuits and power cells design used in these converters. The number of output voltage levels, $m$, can be estimated with (1).

$$
m=2 N+1
$$

Where $N$ is the number of total bridge cells configured in one phase leg of CHB or the number of total chopper cells configured in one arm of MMC.

The common modulation techniques used in these converters can be classified as carrier-based modulation techniques, Space-Vector-Modulation (SVM) methods, and Selective Harmonic Elimination (SHE) $[16,18,20]$. Carrier-based modulation is simple for implementation but this method introduce high switching losses. Whereas, the complexity of the SVM algorithm increases exponentially with the increasing number of power cells employed. Therefore, this paper choose to evaluate the converters using LevelShifted-PWM modulation. This technique uses identical carrier wave for modulation, which is highly suitable for FPGA implementation [21]. The operation principle and Level-Shifted-PWM schemes of CHB and $\mathrm{MMC}$ will be summarized in the following sub-sections. 


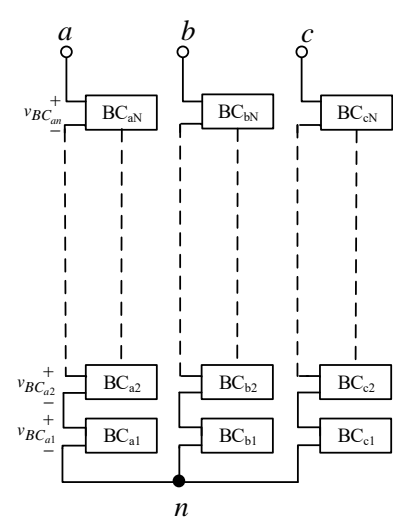

(a) $\mathrm{CHB}$

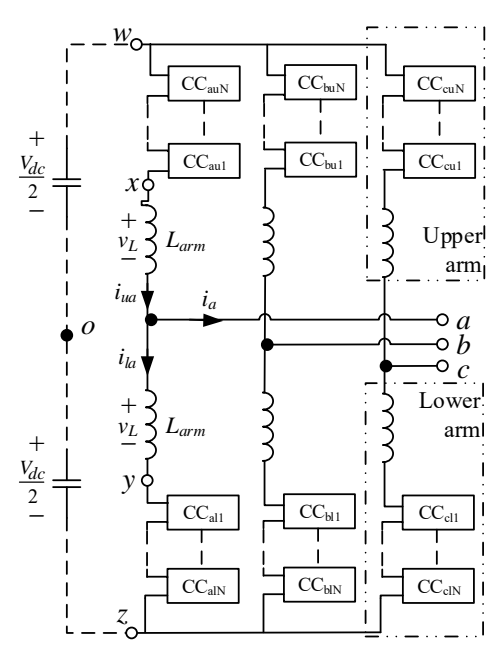

(b) MMC

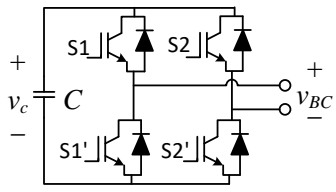

(c) Bridge Cell (BC)

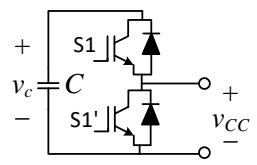

(d) Chopper Cell (CC)

Figure 3. Power circuit of (a) cascaded h-bridge converter (CHB), (b) modular multilevel converter (MMC),

(c) bridge cell (BC), and (d) chopper cell (CC)

\subsection{Cascaded H-bridge converter (CHB)}

Cascaded H-Bridge (CHB) converter is configured by a number of bridge cells connected in series per phase leg as shown in Figure 3(a). A unit of Bridge Cell (BC) employs four units of power semiconductor (S1, S1', S2, and S2') and a capacitor, $C$. The capacitance of each bridge cell is identical to form a symmetric $\mathrm{CHB}$. The power semiconductors are switching in pair to generate three voltage levels $\left(v_{c}, 0,-v_{c}\right)$ at the bridge cell terminal, $v_{B C}$. Each phase output voltage, $v_{p n}$, can be determined by summing up all voltage values given by the bridge cells, which are connected in the same phase leg.

$$
v_{p n}=\sum_{i=1}^{N} v_{B C_{p i}}
$$

Where $N$ is the number of total bridge cells configured in one phase leg and $p$ represents phases a-b-c. In order to obtain balance three-phase AC voltages, all phase legs should consist equal numbers of bridge cells.

To implement Level Shifted-PWM (LS-PWM) method, three sinusoidal waves with $120^{\circ}$ phase shift are used as the modulating signals for each phase. These signals are formulated as follows:

$$
\begin{aligned}
& v_{\text {mod_a }}=V_{m} \sin 2 \pi f_{m} t \\
& v_{\text {mod_b }}=V_{m} \sin \left(2 \pi f_{m} t-\frac{2 \pi}{3}\right) \\
& v_{\text {mod_c }}=V_{m} \sin \left(2 \pi f_{m} t+\frac{2 \pi}{3}\right)
\end{aligned}
$$

Where $V_{m}$ represents the peak amplitude and $f_{m}$ refers to the frequency of modulating wave. In addition, $2 \mathrm{~N}$ units of carrier waves are demanded to control $N$ units of bridge cells per phase. These carrier waves are identical, a basic carrier wave, $v_{C w_{C H B}}$, can be expressed by the following equation.

$$
v_{c w_{C H B}}=\left\{\begin{array}{c}
\frac{2 f_{c}}{N} t, 0<t<\frac{1}{2 f_{c}} \\
-\frac{2 f_{C}}{N} t+\frac{2}{N}, \frac{1}{2 f_{C}}<t<\frac{1}{f_{C}}
\end{array}\right.
$$

Where $N$ is the number of total bridge cells configured in one phase leg and $f_{c}$ denotes the carrier wave frequency. This basic carrier wave is then duplicated and shifted accordingly for modulation. The converter employs four units of bridge cell per phase. Each bridge cell will be controlled by two units of carrier waves, namely $v_{C w i_{C H B}}$ and $v_{C w(i+N)_{C H B}}$.

Int J Pow Elec \& Dri Syst, Vol. 10, No. 3, Sep 2019 : 1157 - 1166 


$$
\begin{aligned}
& v_{C w i_{C H B}}=v_{C w_{C H B}}+\frac{1}{N}(i-1) \\
& v_{C w(i+N)_{C H B}}=v_{C w_{C H B}}-\frac{i}{N}
\end{aligned}
$$

The power switches in each bridge cell are controlled based on the following conditions:

$$
\begin{aligned}
& \mathrm{S} 1 \text { of } B C_{p i} \text { is triggered } \mathrm{ON} \text { when } v_{\text {mod_p }}>v_{c w i_{C H B}} \\
& \mathrm{~S} 2 \text { of } B C_{p i} \text { is triggered } \mathrm{ON} \text { when } v_{\text {mod_p }}<v_{c w(i+N)_{C H B}}
\end{aligned}
$$

Where $p$ represents phase-a, phase-b or phase-c. When S1 and S2' are triggered on, a bridge cell will contribute a capacitor voltage, $v_{c}$, to the output phase voltage. Inversely by turning on S1' and S2 switches, a negative capacitor voltage, $-v_{c}$, will be presented. Zero voltage level will be achieved by setting (S1 and S2) or (S1' and $\mathrm{S} 2$ ') at active status.

\subsection{Modular multilevel converter (MMC)}

The power circuit of Modular Multilevel Converter (MMC) shown in Figure 3(b) illustrates that each phase leg consists of two arms where a number of chopper cells are connected in series. The number of chopper cell must be equivalent in each arm to ensure a symmetry AC voltage waveform will be produced. An arm inductor, $L_{a r m}$, inserted near the AC terminal are mainly employed to suppress the circulating current and limit the AC current arising rate when fault current is located within the MMC [22]. A chopper cell contains a capacitor, $C$, and two units of power switch, $S 1$ and $S 1$ '. These components are configured in halfbridge configuration as shown in Figure 3(d). Power switches are triggered complementary to produce two voltage levels (either $0 \mathrm{~V}$ or $v_{c} \mathrm{~V}$ ) at the chopper cell terminal, $v_{C C}$. Thus, the arm voltages, $v_{w x}$ and $v_{y z}$, can be expressed as follows:

$$
\begin{aligned}
& v_{w x}=\sum_{i=1}^{N} v_{c c_{p u i}} \\
& v_{y z}=\sum_{i=1}^{N} v_{c c_{p l i}}
\end{aligned}
$$

Where $N$ is the number of total chopper cells configured in one arm and $p$ represents phase-a, phase-b or phase-c. The posititve direction of the upper and lower arm current for phase-a, $i_{u a}$ and $i_{l a}$, are illustrated in Figure 3 (b). These currents form the AC current as follows:

$$
i_{p}=i_{u_{p}}-i_{l_{p}}
$$

Where $p$ represents phase-a, phase-b or phase-c. The pole voltage, $v_{a o}$, can be derived as follows:

$$
v_{a o}=\left(\frac{v_{d c}}{2}-v_{L}-v_{w x}\right)=\left(-\frac{v_{d c}}{2}+v_{L}+v_{y z}\right)
$$

To implement Level Shifted-PWM (LS-PWM) method in MMC, six modulating signals and $N$ units of carrier waves are demanded. The upper arm and lower arm modulating signals are shifted $180^{\circ}$ apart, as given belows:

$$
\begin{array}{ll}
v_{\text {mod_au }}=V_{m} \sin \left(2 \pi f_{m} t+\pi\right) & v_{\text {mod_al }}=V_{m} \sin 2 \pi f_{m} t \\
v_{\text {mod_bu }}=V_{m} \sin \left(2 \pi f_{m} t-\frac{2 \pi}{3}+\pi\right) & v_{\text {mod_bl }}=V_{m} \sin \left(2 \pi f_{m} t-\frac{2 \pi}{3}\right) \\
v_{\text {mod_cu }}=V_{m} \sin \left(2 \pi f_{m} t+\frac{2 \pi}{3}+\pi\right) & v_{\text {mod_cl }}=V_{m} \sin \left(2 \pi f_{m} t+\frac{2 \pi}{3}\right)
\end{array}
$$

Where $V_{m}$ and $f_{m}$ represents the peak amplitude and frequency of modulating wave. $N$ number of identical carrier waves are demanded to control $N$ units of chopper cells located in each arm of the MMC. A basic carrier wave for MMC, $v_{c w_{M M C}}$, is formulated as follows:

$$
v_{c w_{M M C}}=\left\{\begin{array}{c}
\frac{4 f_{c}}{N} t-1,0<t<\frac{1}{2 f_{C}} \\
-\frac{4 f_{c}}{N} t+\frac{2}{N}-1, \frac{1}{2 f_{c}}<t<\frac{1}{f_{c}}
\end{array}\right.
$$


Where $N$ is the number of total chopper cells configured in one arm and $f_{c}$ denotes the carrier wave frequency. This basic carrier wave is then duplicated and shifted vertically for modulation. Each chopper cell will be controlled by $v_{C w i_{M M C}}$ as formulated in the following equation.

$$
v_{c w i} i_{M C}=v_{c w_{M M C}}+\frac{2(i-1)}{N}
$$

The switching condition of power switch, S1, in each chopper cell is summarized as:

$$
\begin{aligned}
& \mathrm{S} 1 \text { of } C C_{p u i} \text { is triggered } \mathrm{ON} \text { when } v_{\text {mod_au }}>v_{c w i_{M M C}} \\
& \mathrm{~S} 1 \text { of } C C_{p l i} \text { is triggered } \mathrm{ON} \text { when } v_{\text {mod_al }}>v_{c w i_{M M C}}
\end{aligned}
$$

When switch $\mathrm{S} 1$ is triggered on, the capacitor voltage, $v_{c}$, will be presented at the chopper cell terminal.

In summary, the CHB output voltage waveform, $v_{a n}$, and the pole voltage waveform, $v_{a o}$, of MMC are presented side by side in Figure 4. It is clearly shown that MMC produces a more sinusoidal voltage waveform with smaller amplitude. The magnitude of the output voltage waveform can be tuned using amplitude modulation ratio, $m_{a}$, for both converters. For linear modulation, the peak voltage of the modulating wave is limited to maximum of 1 [p.u.] as given in (18).

$$
m_{a}=\frac{V_{m}}{1}
$$

Where $V_{m}$ represents the peak amplitude of modulating wave.

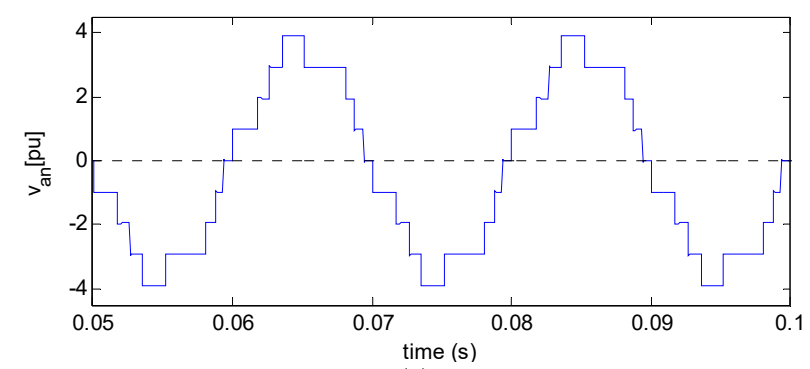

(a)

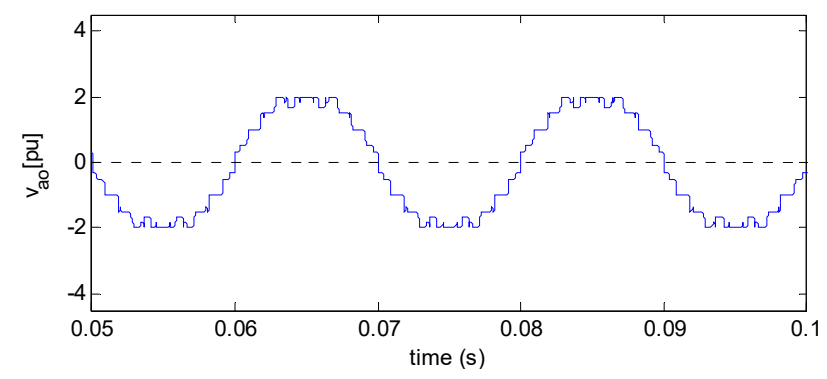

(b)

Figure 4. Phase-a output voltage waveforms of (a) CHB and (b) MMC

\section{SIMULATION VERIFICATION}

Two traction substation models as illustrated in Figure 2 are constructed with the main aim to compare the performance of $\mathrm{CHB}$ and $\mathrm{MMC}$ as recuperating converter. These simulation models used a 900 $\mathrm{V}$ constant dc source voltage to represent the achievable maximum regenerative braking voltage, $V_{d c}[23$ ]. In addition, the AC grid and rectifier transformer are modeled as $R L$-load configured in $Y$-connection. The load parameters are fixed according to [16]. Table 1 presents the simulation parameters.

Int J Pow Elec \& Dri Syst, Vol. 10, No. 3, Sep 2019 : 1157 - 1166 
Table 1. Simulation parameters

\begin{tabular}{lcc}
\hline & $\begin{array}{c}\text { Cascaded H- } \\
\text { Bridge Converter }\end{array}$ & $\begin{array}{c}\text { Modular Multilevel } \\
\text { Converter }\end{array}$ \\
\hline Number of power cell per phase, $N$ & 4 & 8 \\
Capacitor voltage level per power cell, $V_{c}$ & $225 \mathrm{~V}$ & $225 \mathrm{~V}$ \\
Arm inductor, Larm & $\mathrm{NA}$ & $60 \mu \mathrm{H}$ \\
Resistive Load per phase, $R$ & $0.3 \Omega$ & $0.3 \Omega$ \\
Inductive Load per phase, $L$ & $50 \mu \mathrm{H}$ & $50 \mu \mathrm{H}$ \\
Frequency Modulation Index, $m_{f}$ & 21 & 21 \\
Amplitude Modulation Index, $m_{a}$ & 0.545 & 1 \\
Amplitude ratio of triangular waves, $\hat{v}_{c w i}$ & 0.25 & 0.5 \\
\hline
\end{tabular}

The first simulation model implements a three-phase CHB as the recuperating converter. The CHB consists of four bridge cells in each phase. Four units of ideal IGBT power switches are used to form the bridge cell. The capacitor of each bridge cell is modelled as a constant voltage source. The dc source is set to $225 \mathrm{~V}$ with the assumption that the bridge cells in one phase leg equally divided the $V_{d c}$. Figure 5 (a) shows the modulation and carrier waves of LS-PWM in CHB. Eight units of identical carrier waves are employed. These carrier waves are set to $1050 \mathrm{~Hz}$ with an amplitude of $0.25 \mathrm{~V}$ each. Three units of $50 \mathrm{~Hz}$ modulating waves are used as the reference signals for modulation. The amplitude of the modulating wave, $V_{m}$ is set to $0.545 \mathrm{~V}$ with the aim to ensure that the effective value of the output line-line voltages will reach $585 \mathrm{~V}$ [9].

The second simulation model employs a three-phase MMC as the recuperating converter. This converter is modeled with four units of chopper cell per arm. Each chopper cell is modelled using two units of ideal IGBT power switch and a fixed dc source is used to represent the capacitor voltage. It is documented that at every instant, half numbers of chopper cell integrated within one-phase leg will be activated, therefore the capacitor voltage of each chopper cell is set to $225 \mathrm{~V}\left(V_{d c} / 4\right)$. The arm inductance is set to $60 \mu \mathrm{H}$ in this simulation. The LS-PWM technique used in MMC just requires four identical carrier waves with six units of modulating waves. The switching frequency of the carrier wave is set to $1050 \mathrm{~Hz}$ and the amplitude of each carrier wave is set to $0.5 \mathrm{~V}$. The amplitude of modulating waves are set to a maximum of $1 \mathrm{~V}$ (linear modulation). Figure 5 (b) and (c) clearly illustrate all the modulation signals used for LS-PWM in MMC.

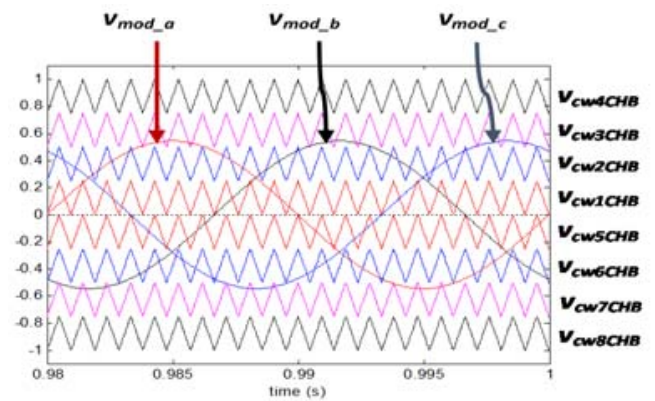

(a)

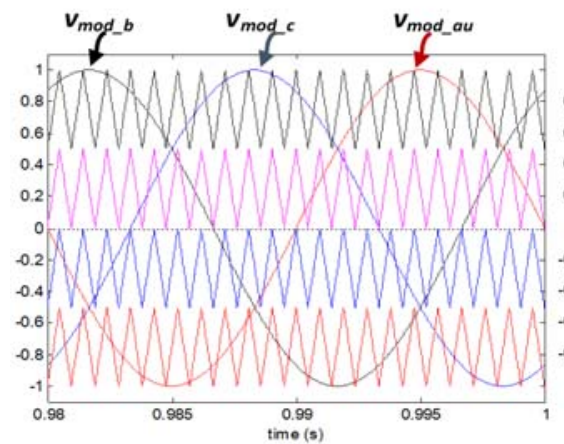

(b)

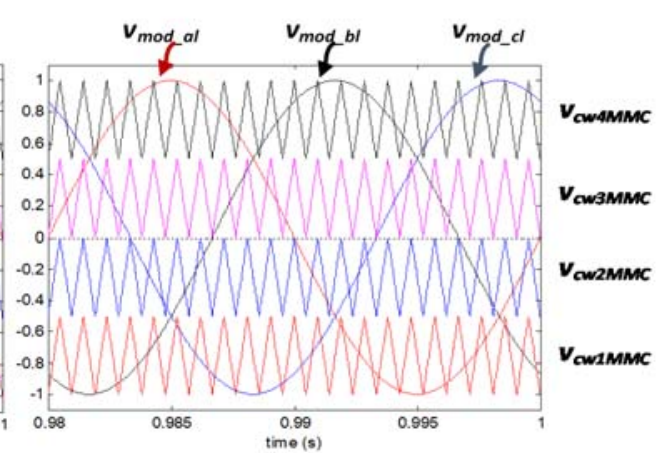

(c)

Figure 5: LS-PWM for (a) CHB with $m_{a}=0.545$, (b) upper arm MMC with $m_{a}=1.0$, and (c) lower arm MMC with $m_{a}=1.0$. 
Figure 6 shows the simulation results of currents and voltages waveforms for two proposed recuperating converters. CHB converter results are tabulated in column (a) while MMC results are shown in column (b). All voltages and currents waveforms are balance. Figure 6 (a) i. depicts three phase-voltages waveforms generated by CHB. Since the amplitude modulation index, $m_{a}$ is set to 0.545 , only three units of bridge cell (per phase) are actively triggered. Therefore, seven-level output phase-voltages are obtained with the voltage harmonic distortion $\left(T H D_{v}\right)$ is measured at $25.06 \%$. On the other hand, all the chopper cells in MMC are being actively switched to produce a nine-level output phase-voltages (Figure 6 (b) i.). These voltages are more sinusoidal. The voltage harmonic distortion $\left(T H D_{v}\right)$ is measured around $8 \%$. Figure 6 ii. and iii. illustrate all line-line voltages generated by (a) CHB and (b) MMC. CHB produces a nine-level voltage waveforms with the effective fundamental line-line voltage documented at $585.1 \mathrm{~V}$ and $T H D_{v}$ equal to $16.27 \%$. MMC generates a more sinusoidal line-line voltage waveforms, however the effective fundamental line-line voltage is captured at $546.3 \mathrm{~V}$. Although, the rms value of the line-line voltages are about $6.6 \%$ less than the demanded $585 \mathrm{~V}$, the voltage harmonic distortion is complied with the $8 \%$ industrial standard. Lastly, three phase-currents waveforms are given in Figure 6 iv. CHB produces a more distorted current waveforms $\left(T H D_{i}=13.83 \%\right)$ compare to MMC. Good quality current waves with the $T H D_{i}$ approximately $3 \%$ is given by MMC. Table 2 tabulates the THD indexes produced by two proposed converters. Based on the voltage and current waveforms quality, MMC is concluded as the potential recuperating converter for future DC railway electrification system.

i.
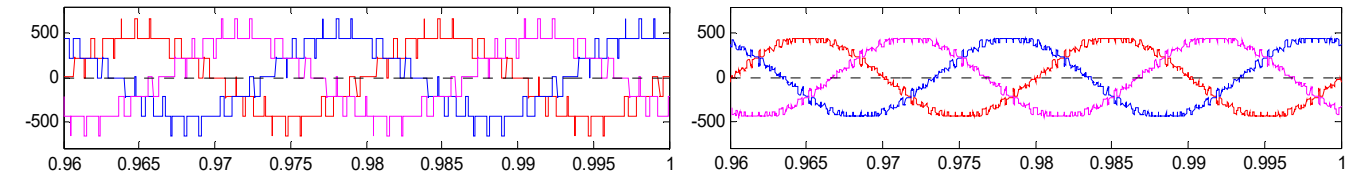

ii.
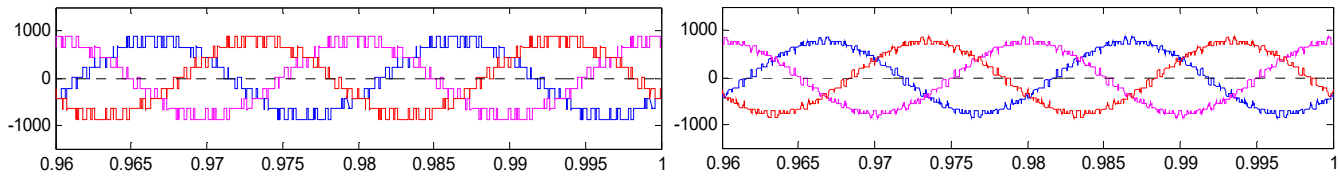

iii.
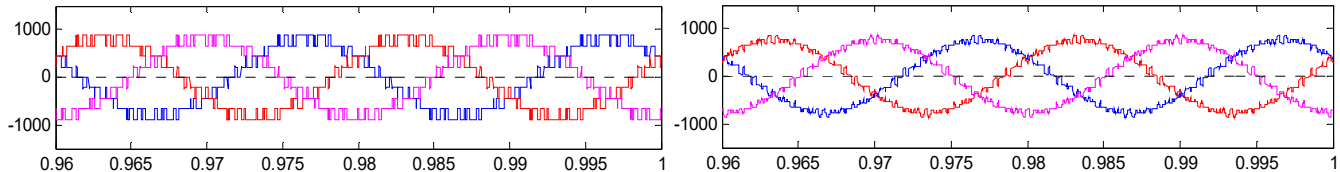

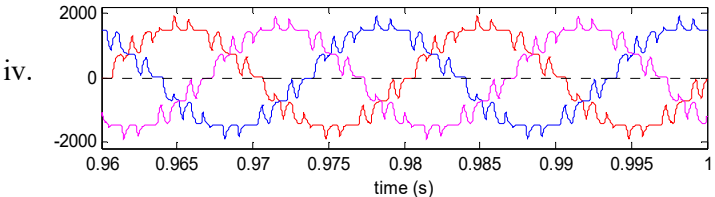

(a)

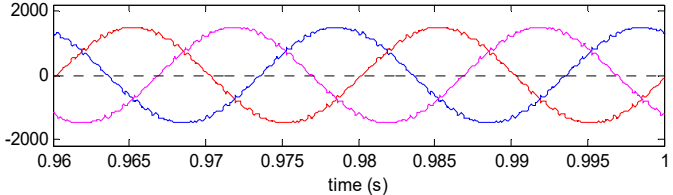

(b)

Figure 6: Simulation results of (a) CHB and (b) MMC. The sub-plots show: i. phase voltages waveforms, $\left(v_{a n}, v_{b n}, v_{c n}\right)$, ii. line-line voltages waveforms $\left(v_{a b}, v_{b c}, v_{c a}\right)$, iii. line-line voltages waveforms $\left(v_{c b}, v_{a c}, v_{b a}\right)$, iv. phase currents waveforms $\left(i_{a}, i_{b}, i_{c}\right)$.

Table 2. Total harmonic distortion indexes comparison between two potential recuperating converters.

\begin{tabular}{lcc}
\hline & $\begin{array}{c}\text { Cascaded H-Bridge } \\
\text { Converter (CHB) }\end{array}$ & $\begin{array}{c}\text { Modular Multilevel } \\
\text { Converter (MMC) }\end{array}$ \\
\hline $\begin{array}{l}\text { Phase voltage } \\
\text { distortion, } T H D_{v}\end{array}$ & $25.06 \%$ & $7.99 \%$ \\
$\begin{array}{l}\text { Line-line voltage } \\
\text { distortion, } T H D_{v}\end{array}$ & $16.27 \%$ & $7.99 \%$ \\
$\begin{array}{l}\text { Phase current } \\
\text { distortion, } T H D_{i}\end{array}$ & $13.83 \%$ & $2.98 \%$ \\
\hline
\end{tabular}

Int J Pow Elec \& Dri Syst, Vol. 10, No. 3, Sep 2019 : 1157 - 1166 


\section{CONCLUSION}

The regenerative braking energy of Light-Rail-Transit (LRT) vehicle can be transferred back to the ac grid using recuperating converter system. Literatures show that the conventional six-pulse inverter systems had been widely used. However, this system introduces harmonics at AC terminals. Therefore, passive filters are demanded. In order to minimize the size of the passive filters, this paper has proposed to replace the conventional regenerative inverter system with a multilevel converter. Two cascaded topologies multilevel converter, namely Cascaded H-Bridge (CHB) converter and Modular Multilevel Converter (MMC) are reviewed and analysed in this paper. Two traction substation simulation models are developed and integrated with a $\mathrm{CHB}$ or an $\mathrm{MMC}$ as its recuperating converter. Both $\mathrm{CHB}$ and $\mathrm{MMC}$ are designed with the aim to produce a nine-level output phase voltage using Level-Shifted-Pulse-Width-Modulation technique. The simulation results show that MMC is more suitable to use as a recuperating converter as it produces good quality of voltage and current waveforms. The Total Harmonics Distortion indexes are comply with the industrial standard, i.e. less than $8 \%$ of voltage harmonic and $5 \%$ of current harmonic. However, the line-line voltages produced by MMC are slightly lower than the secondary winding of the rectifier transformer rating. This issue can be solved by injecting third-order harmonic voltage component as a common mode signal for modulation [24], [25].

\section{ACKNOWLEDGEMENTS}

The authors are pleased to express their appreciation to the Ministry of Education (MOE), Malaysia for sponsoring the Fundamental Research Grant Scheme (FRGS) to conduct this research. Project Code: FRGS/1/2016/TK04/UNITEN/02/1.

\section{REFERENCES}

[1] C. J. Goodman, "Overview of Electric Railway systems and the calculation of train performance," in The 9th Institution of Engineering and Technology Professional Development Course on Electric Traction Systems, Manchester, pp. 1-24, 2006.

[2] P. Johnson, S. Brown, "A simple in-cab schedule advisory system to save energy and improve on-time performance," in IET Conference on Railway Traction Systems, Birmingham, pp. 1-5, 2010.

[3] V. Gelman, "Braking energy recuperation-reversible thyristor-controlled rectifiers," IEEE Vehicular Technology Magazine, vol. 4, no. 3, pp. 82-89, 2009.

[4] H. Ibaiondo, A. Romo, "Kinetic energy recovery on railway systems with feedback to the grid," in 14th International Power Electronics and Motion Control Conference, Ohrid, pp. 94-97, 2010.

[5] S-H Song, S-J Jang, H-J Bang, C-Y Won, "Regeneration inverter system for DC traction with harmonic reduction capability," in 30th Annual Conference of the IEEE Ind. Electronics Society, Busan, pp. 1463-1468, 2004.

[6] R. D. White, "AC/DC Railway electrification and protection," in IET 13th Professional Development Course on Electric Traction Systems, London, pp. 1-42, 2014.

[7] IEEE Recommended Practice and Requirements for Harmonic Control in Electric Power Systems, IEEE, 2014.

[8] K. Hirahara, "Malaysia kelana jaya line power supply system," Meiden Review, vol. 156, no. 3, pp. 48 - 51, 2012.

[9] M. Rajaratnam, P. Guyard, N. Mazet, "Plan of instruction-traction power sub-station (TPSS) overall system description," Konsortium CMC-COLAS-UNIWAY, Kuala Lumpur, 2016.

[10] D. Iannuzzi, F. Murolo, P.Tricoli, "A sample application of SC storage system for suburban transit," in Int. Conf. Elect System for aircraft, railway and ship propulsion, Bologna, pp. 1-7, 2010.

[11] M. Thong, A. Cheong, "Energy efficiency in singapore's rapid transit system," Journeys, pp. 38-47, 2012.

[12] M. Chymera, A. C. Renfrew, et.al, "Simplified power converter for integrated traction energy storage," IEEE Trans. On Vehicular Technology, vol. 60, no. 4, pp. 1374-1383, 2011.

[13] W. A. G. de Jager, M. Huizer, E. K. H. van der Pols, "Implementation of active regeneration unit in a traction substation," in 16th European Conference on Power Electronics and Applications, Lappeenranta, pp. 1-9, 2014.

[14] D. Cornic, "Efficient recovery of braking energy through a reversible dc substation," in Electrical Systems for Aircraft, Railway and Ship Propulsion, Bologna, pp. 1-9, 2010.

[15] S-J Jang, C-Y Choi, C-H Bae, S-H Song, C-Y Won, "Study of regeneration power control inverter for DC tracton with active power filter ability," in 31st Annual Conference of IEEE Industrial Electronics Society, Raleigh, pp. 1271-1277, 2005.

[16] A. Awalludin, C. L. Toh, "Harmonic mitigation in traction supply substation using cascaded h-bridge converter," International Journal of Power Electronics and Drive Systems (IJPEDS), vol. 9, no. 4, pp. 1745-1754, 2018.

[17] S. Kouro, M. Malinowski, K. Gopakumar, J. Pou, L. G. Franquelo, B. Wu, J. Rodriguez, M. A. Perez, J. I. Leon, "Recent advamces and industrial applications of multilevel converters," IEEE. Trans. on Ind. Electronics, vol. 57, no. 8, pp. 2553-2010, 2010.

[18] J. I. Leon, S. Vazquez, L. G. Franquelo, "Multilevel converters: control and modulation techniques for their operation and industrial applications," Proceedings of The IEEE, vol. 105, no. 11, pp. 2066-2081, 2017.

Comparative study of two potential recuperating converters in DC railway electrification (Z. $H$. Choi) 
[19] I. H. Shanono, N. R. H. Abdullah, A. Muhammad, "A survey of multilevel voltage source inverter topologies, controls and applications," International Journal of Power Electronics and Drive Systems (IJPEDS), vol. 9, no. 3, pp. 1186-1201, 2018

[20] S. K. Dash, B. Nayak, J. B. Sahu, "selective harmonic elimination of an eleven level inverter using whale optimization technique," International Journal of Power Electronics and Drive Systems (IJPEDS), vol. 9, no. 4, pp. 1944-1951, 2018.

[21] C. L. Toh, L. E. Norum, "VHDL implementation of capacitorvoltage balancing control with level-shifted pwm for modular multilevel converter," International Journal of Power Electronics and Drive System (IJPEDS), vol. 7, no. 1, pp. 94 - 106, 2016.

[22] Q. Tu, A. Xu, H. Huang, J. Zhang, "Parameter design principle of the arm inductor in modular multilevel converter based HVDC," in Internatinal Conference on Power System Technology, Hangzhou, pp. 1-6, 2010.

[23] R. Vial, D. Riu, N. Retiere, "Simulating calculations and optimization design of a new HVDC supply power for light rail system," in 36th Annual Conference on IEEE Industrial Electronics Society, Glendale, pp.2364-2369, 2010.

[24] G. Guo, Q. Song, W. Yang, Y. Wang, W. Liu, H. Rao, S. Xu, "Application of third-order harmonic voltage injection in a modular multilevel converter," IEEE Trans. on Ind. Electronics, vol. 65, no. 7, pp. 5260 - 5271, 2018.

[25] R. Li, J. E. Fletcher, B. W. Williams, "Influence of third harmonic injection on modular multilevel converter-based high-voltage direct current transmission systems", IET Generation Transmission \& Distribution, vol. 10, no. 11, pp. 2764-2770, 2016.

\section{BIOGRAPHIES OF AUTHORS}

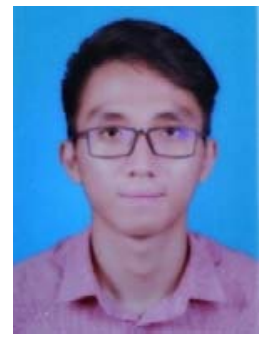

Zhen Hang Choi has received First Class in B. Eng. degree in electronics and communication engineering from University Tenaga Nasional (UNITEN), Kajang, Malaysia in 2018. During his study, his research interests comprise of power electronics, field programmable gate array logic design and cryptographic. Besides, he used to be a Member of the IET Student Chapter. He is also awarded an Excellent Student Award from UNITEN. Currently, he is a Design Project Engineer in Honeywell, Malaysia.

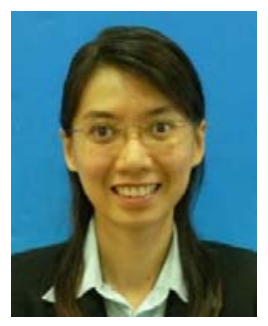

Chuen Ling Toh received the B. Eng. and M. Eng. degree in electrical engineering, both from Universiti Teknologi Malaysia (UTM), Skudai, Malaysia, in 2002 and 2005 respectively; and her Ph.D in Electrical Power Engineering from Norwegian University of Science and Technology (NTNU), Trondheim, Norway, in 2014. Currently, she is a Senior Lecturer at the Universiti Tenaga Nasional, Kajang, Malaysia. Her teaching and research interests include the field of power electronics, motor drive systems and field programmable gate array applications. She is also a Member of IEEE Power Electronics Society (PELS) Malaysia Chapter.

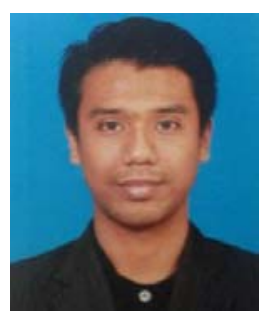

Muhammad Hairi bin Zainol Hilmi received his Bachelor Degree in Electrical \& Electronics Engineering from Universiti Tenaga Nasional (UNITEN), Malaysia in 2011 and currently pursuing Master in Electrical Engineering at UNITEN. He work as an electrical engineer in industrial since 2011 with good technical knowledge in Uninterruptible Power Supply (UPS), rectifiers, inverters, batteries and transformers. His research interest includes power electronics converter design and power system. He is registered with the Board of Engineers Malaysia (BEM) and also a graduate member of Institution of Engineers, Malaysia (IEM). 